\title{
HOW BORSA ISTANBUL (BIST) REACTS TO THE NOVEL CORONAVIRUS: THE COVID-19 CASE
}

\author{
BORSA İSTANBUL'UN YENI KORONAVİRÜSE TEPKİSİ: COVID-19 \\ VAKASI
}

Mehtap ÖNER ${ }^{*}$ iD
Aslı AYBARS $^{* *}$ iD

\begin{abstract}
The purpose of this study is to investigate the response of the Turkish stock market to the novel coronavirus pandemic. To probe the issue, a dataset based on a total of 23 selected Borsa Istanbul (BIST) subindices of BIST Industrials, Services, and Financial indices for the period between 20 March, 2020 and 31 December, 2020 is utilized together with the growth in the weekly numbers of COVID-19 new cases and deaths both for Turkey and the world. A total of four models are run using panel data analysis on 943 index-week observations. The results of the one-way random effects models with time effects reveal that BIST indices react negatively to the growth in weekly COVID-19 new case and death numbers for both Turkey and the world. Further findings as to the control variables show that while Credit Default Swap (CDS) figures reduce selected stock index returns, Chicago Board Options Exchange Volatility Index figures known as Fear Index (VIX) are found to increase them during the observation period.
\end{abstract}

Keywords: COVID-19, pandemic, stock market, index return, panel data

JEL Classification: C33, E44, G12, I15

Öz

$\mathrm{Bu}$ çalışmanın amacı Borsa İstanbul'un yeni koronavirüs pandemisine karşı nasıl tepki verdiğini araştırmaktır. Bu amaçla Borsa İstanbul'un BIST Sinai, Hizmetler ve Finansal endeksleri altında yer alan 23 alt endeks ve Türkiye ile dünyadaki COVID-19 vaka ve ölüm sayılarındaki haftalık büyüme oranları 20 Mart 2020 ve 31 Aralık 2020 tarihlerini kapsayacak şekilde kullanılmıştır. Her biri 943 gözleme dayanan toplam dört model, panel veri yöntemi kullanılarak analiz edilmiştir. Tek yönlü zaman etkili tesadüfi etkiler modeline göre BIST endeksleri Türkiye ve dünyadaki COVID-19 vaka ve ölüm sayılarındaki haftalık artışa

* Assistant Professor, Marmara University, Business Administration Faculty, Accounting and Finance Department, mehtap.oner@marmara.edu.tr, ORCID: 0000-0001-7527-5875.

** Associate Professor, Marmara University, Business Administration Faculty, Accounting and Finance Department, asli. aybars@marmara.edu.tr, ORCID: 0000-0002-7899-2367.

To cite this article: Öner, M. \& Aybars, A. (2021). How Turkish stock market reacts to the novel coronavirus: The Covid-19 case. Journal of Research in Business, 6(1), 69-79.

"Çalışmada Etik Kurul izni gerekmemektedir." 
negatif tepki vermiştir. Kontrol değişkenlerine ait sonuçlar; analiz döneminde seçili endekslerin Kredi Temerrüt Takasındaki (CDS) artışlardan negatif yönde, Korku Endeksi olarak bilinen Chicago Opsiyon Borsası Oynaklık Endeksindeki (VIX) artışlardan ise pozitif yönde etkilendiğini göstermiştir.

Anahtar Kelimeler: COVID-19, pandemi, hisse piyasası, endeks getirisi, panel veri JEL Sinıflaması: C33, E44, G12, I15

\section{Introduction}

The novel coronavirus (COVID-19) started as a regional disease in Wuhan, a city in China's Hubei Province, on 31 December 2019 firstly seen as a case of pneumonia with an unknown cause. On 7 January, 2020; Chinese authorities diagnosed it as a new type of coronavirus. Further, World Health Organization (WHO) China Country Office declared 41 patients suffering from this disease with the first case of death being announced on 11 January, 2020 (WHO, 2020a, p. 1). From this day onward, the number of the cases and deaths quickly spread to other regions and countries, and WHO declared COVID-19 as a global pandemic as of March 11, 2020 (WHO, 2020b, p. 2). As of February 2021 , WHO reports the number of confirmed cases approximately as 112.5 million and deaths as 2.5 million spread around to 223 countries, areas, and territories across the globe (World Health Organization, 2021).

Even though the possible consequences of such a severe and ongoing pandemic cannot accurately be measured yet, it is obvious that economic activity all over the world has been affected and will further be influenced and hindered. The countrywide full and partial lockdowns, restrictions and closure of cross-country borders, social distancing to prevent spread of the disease and resulting loss in active labor force together with associated increase in unemployment, people's anxiety and fear about the future are obviously affecting economic activity, financial markets, and stability of the economies. However, countries around the globe are affected at different extents with different manners, policies, and budgets to cope with the pandemic in that the industrialized, emerging, and poor countries are spending up to $15-20 \%, 6 \%$, and less than $2 \%$ of their GDPs for stimulus packages, respectively (Trotsenburg, 2021). Although there have been successful vaccine developments and applications in various countries in the late 2020 with ongoing attempts on further developments, there is still uncertainty as to how long the pandemic will last, how deathly the disease will be with new mutations, how the governmental reactions and restrictions will continue. As stated by Ashraf (in press), such uncertainty will influence the financial markets as well since it will become more difficult to make predictions about the asset prices. Accordingly, negative stock returns have been found in the stock markets around the world as a result of this uncertainty documented in the works of Al-Awadhi et al. (2020), Ashraf (2020), Chia et al. (2020), Khan et al. (2020), and Fernandez-Perez et al. (2021).

This study attempts to evaluate the influence of the novel coronavirus; namely COVID-19, on the Turkish stock market with data covering the period between 11 March, 2020, when the first COVID-19 case was officially announced, and 31 December, 2020. Using weekly data of growth in confirmed cases and growth in number of deaths in both Turkey and the world as proxies of 
COVID-19 belonging almost to one year, panel data analysis is utilized on selected indices of Borsa Istanbul (BIST) to investigate investors' reactions towards this ongoing pandemic. As a summary, the aim of the study is to explore the nexus between selected BIST index returns and the impact of the recent contagious disease.

As can be seen in the literature review section, the investigated topic is so recent that the published articles usually include data for a relatively short period. Therefore, theoretical and empirical studies are limited. Thus, the contribution of the study to this array of literature mainly arises from the fact that the dataset includes a longer time span. Additionally, the influence of not only the Turkish COVID-19 numbers but also the world numbers are utilized in the models that will be explained in detail below.

The remainder of the study is organized as follows. The next section is devoted to literature review related with the reaction of the stock market returns to the novel coronavirus. Section 3 provides the methodology including the dataset, variables utilized, and the model applied. The findings are documented in Section 4. Finally, the last section summarizes the results, provides discussions, concluding remarks, and suggestions for further studies.

\section{Literature Review}

Literature focusing on the impact of the novel coronavirus pandemic on certain aspects of financial markets has not fully evolved yet as the first case, though due to an unknown cause, was seen on 31 December, 2019 in Wuhan. However, as documented by Contessi and De Pace (2021), instability has spread from China to other countries with major stock indices, specifically European, first starting as initial distress of the stock market which is later followed by collapses.

An analysis conducted by Al-Awadhi et al. (2020) focuses on the impact of COVID-19 on stock returns for the period between 10 January and 16 March, 2020 on Hang Seng Index and Shanghai Stock Exchange Composite Index. The results based on panel data analysis reveal the significant and negative impact of the pandemic proxied by the number of daily confirmed cases and daily deaths on China's stock returns. However, no significant findings have been found between stock returns and COVID-19 when data is segregated according to industrial classification.

Chia et al. (2020) utilize data belonging to the FTSE Bursa Malaysia KLCI Index and eight selected main indices for the period between January 2 and April 30 in 2020 to demonstrate the influence of daily new confirmed cases and deaths due to COVID-19 on stock returns. Findings reveal no significant impact on the returns of different indices. However, firm size is found to be a significant indicator of the returns with larger firms demonstrating less loss in the case of unfavorable market events.

A study based on the Turkish stock market evaluates the influence of the number of reported cases in Turkey, Europe, and the world on BIST main and sectoral index returns for the period between 
January 2 and April 15,2020. Whereas almost all sectors are found to be affected by the contagious virus at different levels; food, beverage, wholesale, and retail trade sectors are affected less (Öztürk et al., 2020).

Evidence on the US stock market with data on S\&P1500 firms shows controversies on an industrial basis in terms of the impact of COVID-19 in that whereas the stock returns of natural gas, food, healthcare, and software industries display positively high returns, returns of crude petroleum, real estate, entertainment, and hospitality sectors have fallen (Mazur et al., 2021). Using data belonging to Russell 3000 index covering 98\% of the US public equity market, Ramelli and Wagner (2020) put forth that industry wise stock returns respond in a different manner and magnitude to COVID-19. While the impact is negative and strong for industries such as energy, consumer services, and real estate, it is positive for telecom services, pharma \& biotech, software \& services, and semiconductors etc. Working on data from stock markets of the US and Canada, $\mathrm{Xu}$ (2021) explores the stock market response to the growth in daily confirmed COVID-19 cases and find the negative influence of the disease on stock markets. Whereas asymmetric return reaction with ups and downs to the cases is observed in Canada, the reaction is symmetric for US markets with a smaller magnitude.

A cross-country study, including the stock indices of 64 countries for an approximately 3-month period between January 22 and April 17, 2020, investigates the reaction of the stock markets to the COVID-19 pandemic. The indicators for this contagious disease are selected to be the daily growth in confirmed cases and the daily growth in deaths. While the overall findings point to the negative response of the stock returns to COVID-19, the impact of growth in confirmed cases is more strongly pronounced in comparison to growth in confirmed deaths (Ashraf, 2020). In a further study, Ashraf (in press) also investigates the mediating role of national culture on stock returns during the recent COVID-19 pandemic. Utilizing a dataset of 43 countries for the January 22 to April 17, 2020 period, the paper documents that the growth in confirmed cases are more influential on the reduction of stock market returns in countries with higher nationallevel uncertainty aversion. The study of Fernandez-Perez et al. (2021) also supports the impact of culture on the reaction of stock markets to this novel disease. With a dataset of 63 countries, it has been documented that countries that display lower individualism and high uncertainty avoidance react more negatively. Another concurrent cross-country study with data belonging to 75 countries for the January-April 2020 period reveals that the daily returns of selected stock market indices are negatively affected by the growth in the number of both cases and deaths resulting from the novel coronavirus. Moreover, these findings are more severe for the case of countries those are less free (Erdem, 2020). A sixteen-country study based on weekly data demonstrates that stock returns are reduced by the growth rate in new cases. Further analyses show that investor attitudes change between COVID-19 and non-COVID-19 periods in that at the beginning of the pandemic, investors do not respond to the news; however, as the virus spreads among the people, a negative reaction in the stock markets is observed (Khan et al., 2020). 
Topcu and Gulal (2020) conduct a cross-country study with data belonging to 26 selected emerging stock markets for the March 10 and April 30, 2020 period. While the negative impact of the pandemic outbreak on stock markets is felt the most in the Asian markets, this impact is the lowest for the European counterparts. One of the other outcomes of the study can be stated as the gradual reduction in the influence of the pandemic on stock market returns during the analysis period. Another crosscountry study performed on 13 selected African countries reveals that the majority of the countries display negative stock market returns as a reaction to COVID-19 with only a few countries displaying insignificant results (Takyi and Bentum-Ennin, 2021).

\section{Methodology}

This study employs panel data analysis to investigate the influence of the novel coronavirus on stock market returns in Turkey. The reason why this methodology is preferred rests on the fact that it combines time-series and cross-sectional data making it more superior due to the enhanced informativeness, variability, and higher degrees of freedom it provides. Furthermore, panel data analysis can overcome heterogeneity and multi-collinearity issues (Baltagi, 2013; Wooldridge, 2002).

\subsection{Data and Variables}

The dataset used in this study belongs to the selected subindices listed on BIST under the major indices, namely; BIST Industrials, BIST Services, and BIST Financials making up a total of 23 indices. The names of the indices together with their tickers are provided in Table 1, below. Initially, a timespan between 11 March, 2020, when the first COVID-19 case is officially announced in Turkey, and 31 December, 2020, when the vaccines are firstly imported to Turkey, is utilized. The reason for selecting this period is to eliminate the potential impact of vaccination on index returns. However, to be able to calculate the growth in the number of weekly COVID-19 new cases and deaths, the final period covers the weeks between 20 March, 2020 and 31 December, 2020, inclusive. It has to be noted that for the periods selected, weekly confirmed case and death numbers for both Turkey and the world together with BIST index returns are incorporated into the 4 models below, which will be detailed in the research design section. The data belonging to the BIST indices and the control variables are extracted from Thomsen Reuters Database. The numbers of confirmed COVID-19 new cases and deaths for Turkey and the world are retrieved from the Turkish Ministry of Health and the web page of ourworldindata.org, respectively.

Table 1: The Subindices Used in The Analysis

\begin{tabular}{|c|c|c|c|c|c|}
\hline \multicolumn{2}{|c|}{ BIST Industrials } & \multicolumn{2}{|c|}{ BIST Services } & \multicolumn{2}{|c|}{ BIST Financial } \\
\hline Name of the Index & Ticker & Name of the Index & Ticker & Name of the Index & Ticker \\
\hline Food, Beverage & XGIDA & Electricity & XELKT & Banks & XBANK \\
\hline Textile, Leather & XTEKS & Telecommunication & XILTM & Insurance & XSGRT \\
\hline
\end{tabular}




\begin{tabular}{|c|c|c|c|c|c|}
\hline Wood, Paper, Printing & XKAGT & Sports & XSPOR & Holding and Investment & XHOLD \\
\hline Chemicals, Petrol, Plastic & XKMYA & Whole and Retail Trade & XTCRT & Real Estate, Investment, Trusts & XGMYO \\
\hline Non-metal Mineral & & & & & \\
\hline Products & XTAST & Tourism & XTRZM & Technology & XUTEK \\
\hline Basic Metal & XMANA & Transportation & XULAS & Information Technology & XBLSM \\
\hline Products, & & & & & \\
\hline Machinery & XMESY & Construction & XINSA & Leasing Factoring & XFINK \\
\hline Mining & XMADN & & & Investment Trusts & XYORT \\
\hline
\end{tabular}

The weekly BIST index returns, which are calculated from closing index values, stand for the dependent variables of respective models. The explanatory variables are the growth in weekly confirmed COVID-19 new cases and deaths in Turkey and the world in line with the studies of AlAwadhi et al. (2020), Ashraf (2020), Khan et al. (2020), and Xu (2021). One of the control variables is selected to be Credit Default Swap (CDS) of Turkey, which is related with the risk of default on the country's debt securities, and can be used as an indicator of risk, financial and macroeconomic stability of the countries (Kartal, 2020). The other control variable is determined to be Chicago Board Options Exchange Volatility Index (VIX), which measures the risk and fear in the stock markets and is regarded to be an investment fear index. It is expected that a rise in CDS is associated with a negative impact on stock markets. Additionally, an increase in VIX is also considered as a sign of uncertainty and decline in stock markets (Öztürk et al., 2020). The summary of variables utilized and their abbreviations are demonstrated in Table 2, below.

Table 2. Variables Utilized and Their Abbreviations

\begin{tabular}{ll}
\hline Abbreviation & Variable \\
\hline IRET & Weekly index return \\
GTRCASE & The growth in number of COVID-19 weekly confirmed new cases in Turkey \\
GTRDEATH & The growth in number of COVID-19 weekly new deaths in Turkey \\
GWCASE & The growth in number of COVID-19 weekly confirmed new cases in the world \\
GWDEATH & The growth in number of COVID-19 weekly new deaths in the world \\
CDS & Sovereign Credit Default Swap \\
VIX & Chicago Board Options Exchange Volatility Index \\
\hline
\end{tabular}

\subsection{Research Design}

Overall, 4 models are developed in the empirical analyses with models (1) and (2) investigating the influence of the growth in number of weekly confirmed new cases and deaths from COVID-19 in Turkey on weekly BIST index returns. Additionally, models (3) and (4) are estimated to investigate the same weekly relationship for the growth in number of confirmed world new cases and deaths for the same period, respectively. In all models, the number of indexweek observations is 943 . The models utilized are displayed in Table 3 with their functional representations, as below. 
Table 3: Models Utilized and Their Representations

\begin{tabular}{cc}
\hline Model & Functional Representations \\
\hline IRET $=f($ GTRCASE, CDS, VIX $)$ & $I R E T_{i t}=\beta_{0}+\beta_{1} G T R C A S E_{i t}+\beta_{2} C D S_{i t}+\beta_{3} V I X_{i t}+\epsilon_{i t}$ \\
\hline IRET $=f($ GTRDEATH, CDS, VIX $)$ & $I R E T_{i t}=\beta_{0}+\beta_{1} G T R D E A T H_{i t}+\beta_{2} C D S_{i t}+\beta_{3} V I X_{i t}+\epsilon_{i t}$ \\
\hline IRET $=f($ GWCASE, CDS, VIX) & $I R E T_{i t}=\beta_{0}+\beta_{1} G W C A S E_{i t}+\beta_{2} C D S_{i t}+\beta_{3} V I X_{i t}+\epsilon_{i t}$ \\
\hline IRET $=f($ GWDEATH, CDS, VIX) & $I R E T_{i t}=\beta_{0}+\beta_{1} G W D E A T H_{i t}+\beta_{2} C D S_{i t}+\beta_{3} V I X_{i t}+\epsilon_{i t}$ \\
\hline
\end{tabular}

In order to identify the estimator to be applied for each of the models, numerous tests are run. Firstly, Likelihood-ratio (LR) Test is conducted to assess the validity of the classical model. The results reveal the presence of unit and/or time effects for all models, which proves that the models are not classical. Further analysis with LR test indicates the presence of only time effects; thus, the models are found to be one-way models. According to the results of the Hausman test, the models are determined to be random effects. Therefore, each of the models utilized is found to be one-way random effects model with time effects. Testing the basic assumptions of panel data models, firstly Levene, Brown and Forsythe's Test for heteroskedasticity is conducted with the results demonstrating the presence of heteroskedasticity. Then, in order to test for autocorrelation Modified Bhargava et al. Durbin-Watson and Baltagi-Wu LBI test are applied, and all the models are found to be free from autocorrelation. Lastly, the results of Pesaran's and Friedman's tests reveal that cross-sectional independence is not present in the models. Accordingly, all of the four models are estimated with random effects models with robust standard errors to correct for the heteroskedasticity problem (Tatoğlu, 2020).

\section{Findings}

Table 4 reports the results of all models. While models (1) and (2) investigate the impact of growth in number of weekly confirmed COVID-19 new cases and deaths for Tukey on the selected BIST indices, respectively; models (3) and (4) evaluate the same relationships for growth in the world case and death figures, respectively.

Table 4: Results of the Models

\begin{tabular}{lcccc}
\hline \multicolumn{4}{c}{ Random-effects GLS regression } \\
\hline Variables & Dependent Variable : IRET & \\
\hline GTRCASE & Model (2) & Model (3) & Model (4) \\
& $-.021^{* * *}$ & & \\
GTRDEATH & $(.006)$ & & \\
& & $-.010^{* * *}$ &
\end{tabular}




\begin{tabular}{|c|c|c|c|c|}
\hline \multicolumn{2}{|l|}{ GWCASE } & \multicolumn{3}{|c|}{$\begin{array}{c}-.102^{* * *} \\
(.030)\end{array}$} \\
\hline GWDEATH & & & & $\begin{array}{c}-.083^{* * *} \\
(.029)\end{array}$ \\
\hline \multirow[t]{2}{*}{ CDS } & $-.000^{\star *}$ & $-.000^{\star *}$ & $-.000^{*}$ & $-.000^{* *}$ \\
\hline & $(.000)$ & $(.000)$ & $(.000)$ & $(.000)$ \\
\hline \multirow[t]{2}{*}{ VIX } & $.002^{\star *}$ & $.002^{* *}$ & $.002^{* *}$ & $.002^{* *}$ \\
\hline & $(.001)$ & $(.001)$ & $(.001)$ & $(.001)$ \\
\hline constant & .021 & .023 & .019 & .019 \\
\hline Number of observations & 943 & 943 & 943 & 943 \\
\hline Number of groups & 41 & 41 & 41 & 41 \\
\hline Wald chi2(9) & 21.67 & 309.37 & 13.65 & 8.77 \\
\hline Prob $>$ chi 2 & 0.000 & 0.000 & 0.003 & 0.033 \\
\hline R-squared between & 0.293 & 0.343 & 0.249 & 0.255 \\
\hline legend & ${ }^{*} p<0.10$ & ${ }^{* *} p<0.05$ & ${ }^{* * *} p<0.01$ & \\
\hline
\end{tabular}

Note: Table 4 reports the estimated coefficients for all models. The weekly data range from 20 March, 2020 to 31 December, 2020. For each variable, upper numbers represent the coefficients, and the numbers in parentheses are standard errors.

The findings for the Turkish new cases and deaths demonstrate the negative influence of the growth in these figures on the returns of the BIST indices during the observation period with the impact of the cases being stronger in comparison to deaths. While $1 \%$ increase in growth in the number of Turkish COVID-19 new cases result in $0.02 \%$ decrease in selected index returns, the same amount of increase in growth figures for deaths result in $0.01 \%$ decrease in selected index returns. The behavior of selected BIST index returns towards the growth in world weekly COVID-19 new cases and deaths suggest the same significant and negative relationships as in the Turkish case and death figures.

The impact of Turkish CDS figures on index returns is negative and significant in line with the expectations for all the models. Accordingly; increase in financial and macroeconomic instability reflected in CDS figures acting as a proxy of risk, reduces index returns. On the other hand, the results related with VIX, which represents fear in the stock markets, are positively and significantly related with the selected BIST index returns contrary to the expectations. However, Ozturk et al. (2020) documents the same positive impact of VIX on Turkish stock indices in line with our findings.

To sum up, the results of the analyses show that Turkish stock markets react negatively to the growth in weekly COVID-19 new case and death numbers for both Turkey and the world.

\section{Conclusion and Discussion}

Even though, COVID-19 is a relatively recent topic with limited data and uncertainties, the interest of practitioners and academicians is increasing to investigate the influence of the novel virus on various financial market indicators. As far as the literature review is concerned, this study is one of the few number of studies probing the reaction of the Turkish stock market indices to the growth in the number of COVID-19 new cases and deaths for both Turkey and the world. The overall evidence 
of this study reveals that the growth in weekly numbers of Turkish and world new case and death figures significantly and negatively impact the returns of the selected BIST indices. Additionally, the selected control variables significantly affect stock index returns in that while CDS figures reduce stock index returns, VIX figures are found to increase them.

This paper is performed as a preliminary study of a sequence of studies related with the response of the stock markets to the novel coronavirus. As this study is conducted for the time span before when the vaccine applications have started, further studies can be performed with a longer period which will allow to incorporate the impact of vaccination efforts. Studies with longer observation periods can be subdivided into shorter ones on the basis of developments in the pandemic and associated governmental policies, which include curfews and vaccination stages. Thus, a comparative analysis can be performed on stock market reaction to the novel coronavirus in stages with different characteristics. In addition to the above stated issues, additional studies can also investigate whether industries are impacted at different levels by COVID-19 using industrial indices.

\section{Author Contribution}

The authors made the literature review, data collection, analysis, and interpretation of the findings online via Zoom platform together with the conclusion and discussion part. They have equal contribution to the whole paper.

\section{Conflict of Interest}

No conflict of interest was reported by the authors.

\section{Financial Support}

The authors have not received any financial support for this study.

\section{References}

Al-Awadhi, A. M., Alsaifi, K., Al-Awadhi, A., \& Alhammadi, S. (2020). Death and contagious infectious diseases: Impact of the COVID-19 virus on stock market returns. Journal of Behavioral and Experimental Finance, $27,1-5$.

Ashraf, B. N. (2020). Stock markets' reaction to COVID-19: Cases or fatalities? Research in International Business and Finance, 54, 1-7.

Ashraf, B. N. (in press). Stock markets' reaction to Covid-19: Moderating role of national culture. Finance Research Letters, Retrieved from https://doi.org/10.1016/j.frl.2020.101857.

Baltagi, B. H. (2013). Econometric Analysis of Panel Data, 5th Edition, England, John Wiley \& Sons Ltd.

Chia, R. C. J., Liew, V. K. S., \& Rowland, R. (2020). Daily new Covid-19 cases, The movement control order, and Malaysian stock market returns. International Journal of Business and Society, 21(2), 553-568. 
Contessi, S., \& De Pace, P. (2021). The international spread of COVID-19 stock market collapses. Finance Research Letters, Retrieved from https://doi.org/10.1016/j.frl.2020.101894.

Erdem, O. (2020). Freedom and stock market performance during Covid-19 outbreak. Finance Research Letters, 36, $1-6$.

Fernandez-Perez, A., Gilbert, A., Indriawan, I., \& Nguyen N. H. (2021). COVID-19 pandemic and stock market response: A culture effect. Journal of Behavioral and Experimental Finance, 29, 1-10.

Kartal, M. T. (2020). The behavior of sovereign credit default swaps (CDS) spread evidence from Turkey with the effect of Covid-19 pandemic. Quantitative Finance and Economics, 4(3), 489-502.

Khan, K., Zhao, K., Zhang, H., YANG, H., Shah, M. H., \& Jahanger, A. (2020). The impact of COVID-19 pandemic on stock markets: An empirical analysis of World Major Stock Indices'. Journal of Asian Finance, Economics and Business, 7(7), 463-474.

Mazur, M., Dang, M., \& Vega, M. (2021). COVID-19 and the March 2020 stock market crash. Evidence from S\&P1500, Finance Research Letters, Retrieved from https://doi.org/10.1016/j.frl.2020.101690.

Öztürk, Ö., Şişman, M.Y., Uslu, H., \& Çıtak, F. (2020). KOVİD-19 pandemisinin Türkiye hisse senedi piyasasına etkileri: Sektörel bir analiz. Hitit Üniversitesi Sosyal Bilimler Enstitüsü Dergisi, 13(1), 56-68.

Ramelli, S., \& Wagner, A. F. (2020). Feverish stock price reactions to COVID-19. The Review of Corporate Finance Studies, 9, 622-655.

Takyi, O., \& Bentum-Ennin, I. (2021). The impact of COVID-19 on stock market performance in Africa: A Bayesian structural time series approach. Journal of Economics and Business, Retrieved from https://doi. org/10.1016/j.jeconbus.2020.105968.

Tatoğlu, F. Y. (2020). Panel Veri Ekonometrisi, Stata Uygulamal, 5. Basım, İstanbul, Beta Yayınları.

Topcu, M. \& Gulal, O. S. (2020). The impact of COVID-19 on emerging stock markets. Finance Research Letters, 36, 1-4.

WHO. (2020a). Novel Coronavirus (2019-nCoV) Situation Report 1, World Health Organization, 21 January 2020, 1-5.

WHO. (2020b). Virtual press conference on COVID-19, World Health Organization, 11 March 2020, 1-17.

Wooldridge, J. M. (2002). Econometric Analysis of Cross Section and Panel Data. London, The MIT Press.

Trotsenburg, A. V. (2021, February 9). COVID-19 response: Where we stand now, and the road ahead. World Bank. Retrieved from https://blogs.worldbank.org/voices/covid-19-response-where-we-stand-nowand-road-ahead.

World Health Organization. (2021, February 26). Numbers at a glance. https://www.who.int/emergencies/ diseases/novel-coronavirus-2019.

Xu, L. (2021). Stock Return and the COVID-19 pandemic: Evidence from Canada and the US', Finance Research Letters, 38, 1-7.

\section{Resume}

Mehtap ÖNER (Assist. Prof.), is Assistant Professor of Finance at Faculty of Business, Marmara University. She holds a Ph.D. in Finance from Marmara University. Her research interests focus on the areas of managerial finance, corporate finance, intellectual capital, and project finance. Her research has appeared in Contemporary Studies in Social Sciences, Journal of Finance Letters, International Journal of Economics and Finance, and Research Journal of Politics, Economics and Management. 
She is currently one of the coordinators of Business Administration Program in English at Marmara University.

Aslı AYBARS (Assoc. Prof.), is Associate Professor of Finance at Faculty of Business, Marmara University. She holds a Ph.D. in Finance from Marmara University. Her research interests focus on the areas of portfolio and investment management, derivative instruments, corporate social responsibility, intellectual capital, and corporate finance. Her research has appeared in International Journal of Productivity and Performance Management, Social Responsibility Journal, Journal of Finance Letters, European Financial and Accounting Journal, and Contemporary Studies in Social Sciences. She is currently one of the coordinators of Business Administration Program in English at Marmara University. 